\title{
ESSAYS
}

\section{Travel Writing and the Integration of East-Central Europe: John Paget's Hungary and}

\section{Transylvania}

Márta Pellérdi

https://doi.org/10.30608/HJEAS/2021/27/1/8

\begin{abstract}
John Paget's travelogue from 1839, Hungary and Transylvania; with Remarks on their Condition, Social, Political, and Economical, makes a clear distinction between the Kingdom of Hungary and the Principality of Transylvania, both under Austrian rule at the time, and the rest of Eastern Europe. In terms of the variety and depth of the descriptions of the social, political, and economic conditions in the East-CentralEuropean country and province, Paget's comprehensive and objective text stands out from the travelogues written about the region in the nineteenth century. This essay demonstrates that Hungary and Transylvania reveals the author's intention to rediscover the history and culture of a neglected European nation who have attempted for centuries, successfully, and often unsuccessfully, to orient their politics toward the West rather than the East. It suggests that despite the occasional colonial discourse, Paget's travelogue is an attempt to economically, politically, and culturally promote the integration of Hungary and Transylvania into the more "civilized" West. (MP)
\end{abstract}

KEYWORDS: travel writing, colonial discourse, East-Central Europe, integration, autoimage, hetero-image, nationalities. 
"If these are the wild Highlanders, I could wish my own folk wilder."

Robert Louis Stevenson

At the beginning of his travels across the formidable and less travelled peripheral regions within the central and eastern provinces of the Austrian Empire, John Paget finds himself about fifty miles away from Vienna, in the former capital of Hungary called Presburg. ${ }^{1}$ Witnessing the heated political debates of the Hungarian Diet held there in 1835, he considers it

extraordinary that none of our newspapers, greedy as they are for information, should ever have given any report of these debates; nor, indeed, ever had a correspondent in Presburg; as for trusting to one in Vienna, it would be as reasonable to expect news of Poland in St. Petersburg; none can be more ignorant of what takes place in Hungary than in Vienna. (I, 34)

This passage from Paget's detailed travel narrative, Hungary and Transylvania; with Remarks on their Condition, Social, Political, and Economical, ${ }^{2}$ reveals that the English, just like the Austrian general public a few miles away from Presburg, were "ignorant" about the gradual political ferment that was to culminate in the Hungarian Revolution of 1848-49. The same was true of the rest of Europe and the world. They were also unaware of the social, economic, ethnographic, geographical, and cultural conditions existing at the time in the remote EastCentral European regions of the Continent, particularly in the Kingdom of Hungary, and the Grand Principality of Transylvania. Paget's book is an attempt to remedy contemporary British ignorance about Hungary and Transylvania, and to rediscover, relocate, and 
reintegrate them into Western Europe, despite the many distinguishing features which make them different.

Katarina Gephardt observes a tendency in British travel writing toward "the application of colonial discourse to a European periphery," revealing a purpose different from those informing the writings of other travelers to more remote and unexplored territories of the world (Gephardt 145). Gephardt argues that such colonial discourse interestingly "modifies the dynamics of differentiation and identification in order to fulfill a different rhetorical purpose, one that sustains the idea of a shared European identity" (Gephardt 145). Paget's text demonstrates a similar intention. Furthermore, it defies features of what Andrew Hammond has referred to as "imagined colonialism" (89). Hammond uses the term to explain certain characteristics of nineteenth-century British travelogues on the Balkans in which perceptions of the "Other" are determined by the sense of national and cultural superiority of the traveler, "signifying the possibility and propriety of national domination" without actual colonization taking place (Hammond 89). In Paget's text the colonial discourse is frequently suspended, if not completely abandoned; instead of latently wishing to conquer and possess, the text reflects the writer's wish to improve and integrate in the name of a common European identity. Discussing national stereotypes, Joep Leersson draws attention to the interplay in literary texts "between those images which characterize the Other (hetero-images) and those which characterize one's own, domestic identity (self-images or auto-images)" (27). In Paget's travel writing the hetero-images of the Other are surprisingly similar to the self-image of the traveler, especially when the Hungarian Protestant gentry and middle-class are described. In addition, Hungary and Transylvania clearly differentiates between the geographically, politically, and economically peripheral Hungary and Transylvania, both under Austrian rule at the time, and the rest of Eastern Europe. ${ }^{3}$ The text reveals the author's intention to re-discover and integrate the culture of a land and its peoples who have been 
forgotten and neglected by the more "civilized" West, and a purpose to embark on a voyage that would ultimately lead to self-discovery. As Helga Quadflieg points out about earlier modern travelers: "[i]n exploring Others, these travelers explore themselves, and in describing Others, they write themselves" (29). Paget's travel narrative about Hungary and Transylvania demonstrates these two external and internal exploratory intentions through the constant parallels between English and Hungarian politics, society, and culture.

\section{Hungary and Transylvania in the context of nineteenth-century travel writing}

The same neglect that early nineteenth-century travelers displayed toward the EastCentral European region can be witnessed in studies on British nineteenth-century travel writing. John Paget's work is rarely mentioned, although an impressive number of studies have been written about his work in Hungarian and Romanian. ${ }^{4}$ In the early Victorian period an increasing number of travel narratives about the more "exotic" and distant parts of the world were being published for British readers. Paget's book was published in 1839, the year when Frances Trollope's bestselling The Domestic Manners of the Americans and Charles Darwin's seminal Journal of Researches also appeared. Although Hungary and Transylvania did not produce such resounding echoes as Trollope's ${ }^{5}$ and, especially, Darwin's influential work, John Murray, the distinguished publisher of travel guides and narratives recognized that there was a growing public interest in discovering the peripheral and relatively uncharted East-Central European areas. According to Paget, Hungary and Transylvania were until then "familiar only in history or romance" (I, 1). During his travels the only English guidebooks that Paget could rely on was the somewhat obsolete 1818 edition of Richard Bright's Travels from Vienna Through Lower Hungary and John Murray's Handbook for Southern Germany (1837). He could also consult several more detailed German travel guides, as he mentions in the preface to his work. But throughout his journey Paget kept a diary, into which he 
conscientiously entered the information that he received from his native informers, mostly members of the Protestant Hungarian nobility, and which he drew on later, when composing his two-volume travel narrative. Paget, who was originally trained as a doctor of medicine, toured Hungary and Transylvania in two phases, from June 1835 until January 1836, interrupting his travels by undertaking another journey to Greece and Turkey, ${ }^{6}$ and resuming his tour in November 1836 until the autumn of next year (Wykes 59).

Paget's motivation was partly personal: his curiosity to become familiar with Hungary and Transylvania was prompted by his acquaintance with Baroness Polixéna Wesselényi, whom he had met in Rome in February 1835 and later married. Murray first published Paget's Hungary and Transylvania in 1839 in two volumes while Paget was staying in London and before he returned permanently to Transylvania to settle down with his wife. After the initial publication, a second and third edition followed in 1850 and 1855 , when increased sympathy towards Hungarians after the cruelly suppressed Revolution of 1848-49 once again made the work popular. ${ }^{7}$ Before the first edition appeared, however, the dusty roads and picturesque regions of Hungary and Transylvania were rarely frequented by Western travelers and tourists.

Paget's Hungary and Transylvania had a notable influence on British travelers and paved the way for further travel narratives about the region, which were published later in the nineteenth century. According to Thomas Kabdebo, Paget's work is significant as "[it] is certainly the most solid, factual and informative book published by a Briton on Hungary" (42). Furthermore, Paget is "very informative" on Transylvania (Kabdebo 43), which cannot be said about the works of his predecessors. Paget's descriptions of Transylvania influenced the travel narratives of Charles Boner and Emily Gerard in the second half of the nineteenth century. These writings, however, did not offer much information about the Hungarian territories lying west of the borders of Transylvania, although the reunification of Hungarian 
and Transylvanian territories had already taken place by that time as a result of the Compromise of $1867 .{ }^{8}$ When Paget's text was written, however, both Hungary and Transylvania enjoyed a separate, special status within the Austrian Empire. In terms of the variety and depth of the descriptions of the social, political, and economic conditions, and the relative objectivity of the text, Paget's comprehensive travel writing does justice to both the Kingdom and the Principality, and stands out from the travelogues written about the region in the nineteenth century.

\section{The adventurous traveler}

Two decades after the defeat of Napoleon in 1815, when the borders of the Continent disappeared and traveling and mass tourism were becoming a common phenomenon, most Western travelers preferred to stop at Vienna without venturing any further. The capital of the Austrian Empire at the time was regarded as the last signpost of western civilization, serving as "the gateway to the East" (Steward 221). Traveling from one end of the continent to the east-central "periphery," Paget laughingly brushes off the warnings of Viennese reports about Hungary:

No roads! no inns! no police! we must sleep on the ground, eat where we could, and be ready to defend our purses and our lives at every moment! In full credence of these reports, we provided ourselves most plentifully with arms, which were carefully loaded, and placed ready for immediate use; . . .. It may however ease the reader's mind to know that no occasion to shoot after more formidable than a partridge or a hare ever presented itself . . . travelling in Hungary was just as safe as travelling in England. (I, 2) 
Although Paget confirms readers' expectations at the beginning of his narrative by "get[ting] off the beaten track," and embarking upon a journey "full of the hope of adventure" (I, 1), he is not the typical romantic traveler described by Carl Thompson, who deliberately encounters "misadventure[s]," and suffers "dangers and discomforts" (189). Upon walking through a Slovak village full of "rough-looking men," for instance, Paget admits that if he had "the brilliant imagination of some travelers," he could invent "an interesting story of terror," but since he does not have any, he "can see danger neither in rough-looking peasants, smiling village girls, or civil citizens" (I, 88-89). The safety of the traveler is ensured even in the remotest places. Pragmatic by nature, he apologizes to readers for "refer[ring] so constantly to the subject of creature comforts" (II, 415), but instead of exaggerating the circumstances and discomforts under which he and his companions traveled, he reassures the reader that they "managed to provide against them tolerably well" (II, 473).

Paget's narrative relies on romantic tropes for the purpose of convincing his readers that the secluded places are exotic enough to be worth discovering, even if they are situated on the periphery of the old Continent. He also reports the legends he has heard among the common folk about castles and superstitions, and has an eye for the picturesque. In Paget's descriptions the words "romantic" and "picturesque" are frequently employed as synonyms for the sake of illustrating the harmony between man-made edifices and natural surroundings, as when he presents the beautiful scenery in the valley of Waag near Presburg in Northern Hungary:

We were strongly recommended to visit the valley of the Waag, as being one of the most picturesque and romantic parts of Hungary. And, if the reader has half the passion I have for following up the course of a river-now sunning himself on its banks, now reposing in the shade of its hanging woods,- if he can lend a credulous 
ear to the legends of its old castles, and please himself with the quaint and simple customs of its secluded denizens - then let him accept the invitation, for he will find much that is to his taste in the Valley of the Waag. (I, 54)

The critical reader of nineteenth-century travel writing can detect a touch of superiority in Paget's condescending approach to the "denizens," mostly peasants living in the valley, who have "quaint and simple customs" and are "secluded," untouched by the effects of western civilization. Irrespective of their nationality, the peasants are often regarded as "picturesque," fit to be sketched in their colorful national costumes by Paget's traveling companion, G. E. Hering, ${ }^{9}$ just like the scenery. At Lake Balaton, near Füred, Paget remembers that "H—— had discovered some very picturesque peasants, whom he persuaded to sit to him" (I, 269). However, the lack of the picturesque also deserves the educated Englishman's critique when he remarks with a touch of annoyance that, unlike the English, Hungarians and other Europeans, even if they happen to be of higher social standing, tend to choose the wrong site for building their homes:

At present, the taste for the picturesque is, perhaps as little felt in Hungary as in almost any country in Europe. The negligence with which the position of a house is commonly chosen, the absence of gardens and parks, or, if present, the bad taste with which they are laid out, and the carelessness with which they are kept, are strong evidence of this deficiency. (I, 250)

Underneath the romantic tropes and occasional colonial discourse, the text reveals that Paget has a wide range of interests. 


\section{Improvement and the road to self-discovery}

Paget begins his narrative by describing the political situation and the political institutions of Hungary, which his attendance at the Hungarian Diet of Presburg in 1835 makes timely. He describes the economic conditions of the country and offers suggestions for improvement. He does not fail to criticize the crumbling remnants of the medieval social structure of the three orders, and wholeheartedly embraces the idea of political and social reform as envisioned by liberal reformers, and also his friend, the Hungarian magnate István Széchenyi. Surprised by the relative freedom of the Hungarian municipalities from Austrian interference, he describes their function and significance in preserving the ancient Hungarian constitution. Paget also shows an interest in education, agriculture, social life, horses, various breeds of cattle, and the different types of wines produced (which he never fails to mention), and generously shares facts and figures when describing economic and monetary transactions.

A naturalist at heart, and in keeping with what Mary Louise Pratt has described as the explorer's and naturalist's innocent "anti-conquest" viewpoint, Paget conscientiously explores the natural riches of the regions he is passing through (26). He describes the silver, gold or salt mines and mining processes in Northern Hungary and Transylvania, and comments on the mineralogical composition of various rock formations, and mineral baths. Readers receive precise and detailed descriptions of the interior of several types of caves he explores. ${ }^{10}$ As an antiquarian, he is interested in history, architecture, legends, and Roman relics. In Paget's narrative readers can easily recognize the discourse of the romantic traveler explorer whose "knowledge," in Carl Thompson's words, "garnered by exploration should ultimately be put to practical, and profitable, use, in a way that advanced British interests around the world" (152). Andrew Hammond also draws attention to travel writers' intentions to promote British business interests as an important feature of colonial discourse and "imagined colonialism" in the Eastern European region, especially in the Balkans in the south (Hammond 100). But for 
Paget, the welfare of Hungary is also important: "I am deeply interested in the welfare of Hungary, and I have thought that one great means of promoting it would be to extend the knowledge of that country in the west of Europe, and more especially in England" (I, vii). Paget's earnest plea for the modernization and integration of Hungary and Transylvania into the economic mainstream of the west is reciprocated by a large number of liberal Hungarian politicians and intellectuals from the nobility and middle-classes. More than a decade before Paget's travels in Hungary and Transylvania took place, the famous Hungarian magnates, Count István Széchenyi and Baron Miklós Wesselényi (his future wife's second cousin), made their own Grand Tour to England, to study the industry, economy, and banking system of Great Britain. They were Hungarian reformers whose example and presence haunts the pages of Paget's two volumes. According to Thomas Kabdebo, "[j]ust as the work and words of Széchenyi had dominated the Hungary section of Dr Paget's work, in the Székely part of Transylvania he found that the pass-word was Wesselényi" (Kabdebo, 45). Although Hungarian liberals and reformers sought to follow the social, economic, and political example of the constitutional monarchy of Great Britain well before the two famous Hungarians' journey to England took place in 1822, Széchenyi and Wesselényi's experience abroad confirmed the general conviction among Hungarians that England's example was the one to follow. Széchenyi's personal efforts at improving transportation by bridge-building and promoting steam-navigation, his founding of important national institutions, such as the Hungarian Academy of Sciences, and his influential writings urging economic and social reform, were partly the results of what he witnessed and experienced when he was abroad. Széchenyi and Wesselényi were exceptions among the aristocracy. Speaking of the absentee and German-speaking magnates, Paget cannot refrain from expressing his own contemptuous opinion of them: "I despise the man who can see nothing good at home, and I hate him who is ashamed of a country which his own neglect tends every day to injure (I, 362-63). 
Although Paget fervently wishes for the economic and social improvement in Hungary and Transylvania, he nostalgically laments the passing away of traditions, and foresees a future when "all these beautiful costumes, and the honest pride and self-esteem they give rise to, must disappear, as soon as the cheap wares of Manchester, or some other cotton capital, gain entrance to these valleys, and drive household manufactures from the field!" (II, 348). The consequences of modernization fall into the category of the "familiar". According to Katharina Gephardt, "nostalgic and aesthetically motivated nineteenth-century travelers to Eastern Europe were "focus[ed] on "othering," and therefore they "resent[ed] the modernization of the region" (172). Like other travelers, Paget is also pleased to encounter the signs of the past. When discussing social life in Klausenburg, ${ }^{11}$ for instance, he is reminded of the long-gone social atmosphere in England and pleased to see that "the habits of society ... in many respects, differ little from those of England about the end of the last century" (II, 503). It is the quaint similarity with the habits of the late eighteenth-century English gentry that Paget sees as an appealing feature of the Hungarian elite, as well as their curiosity and impressive knowledge about Britain.

"Anglomania" in this period was "a cultural phenomenon," as Borbála Bökös points out, which Paget and his friends could easily relate to, and which they found quite flattering (94). For this reason, Paget is astonished by how well-informed Hungarians are about British domestic affairs and culture. Instead of encountering the same ignorance about England that characterizes his English readers, Paget breaks off his narrative several times to marvel at the respect in which his native land is held and at the wealth of information possessed by gentlemen regarding current British domestic affairs:

It is wonderful how eagerly every one asks for information about our Parliament . ... Many seemed to think the House of Commons must needs be the favourite resort of 
everyone, and I have heard young men declare, that they would toil and slave life long for the pleasure of once seeing, and hearing the debates of that house. Not a single great name in either chamber, but was familiar to our host. How did Lord Grey look? What would the Duke of Wellington do? How could Peel hold with the ultra-Tories? Was O’Connell an honest man? Did Stanley really believe all he talked about church property? (I, 150)

In the passage the Irish politician Daniel O'Connell is mentioned, which suggests that wellinformed Hungarians were following Britain's Irish policy most closely, seeing a similarity between Hungary and Ireland in the former's relationship to Austria. ${ }^{12}$ Surprisingly, the educated but poor are also well-informed. In the remote parts of north-eastern Hungary Paget and his traveling companions encounter an old Jewish man in rags, who is familiar with Walter Scott's work. Much to Paget and his companions' surprise, the man 'pulled from his pocket a well-thumbed German translation of Ivanhoe" (I, 121). Paget cannot help but express his amazement:

It is astonishing to an Englishman who knows how ignorant even well-informed persons of his own country are of the literature and politics of a great part of the

Continent, to find the names of the best authors of England familiar as household words among nations of whose very existence the greater part of that country is scarcely aware.” (I, 121)

Traveling in Central and Eastern Europe, the English traveler is usually rewarded by "the discovery of the civilized self and the social prestige" that an Englishman usually enjoys abroad (Hammond 90). But instead of projecting "the conviction of superiority" (Hammond 
90), Paget's text reveals surprise, respect and enthusiasm for a nation in which a large proportion of the nobility and the middle class are ready to introduce reforms in their struggle against the backwardness deriving from outdated structures. Paget is delighted with the modern transformations that have already taken place in the major towns, for instance, in Buda-Pest (then separate twin cities). Pest, especially, is full of "active bustle"; it is a "young and lusty" town (I, 252), and in a short course of time "it has become one of the capitals of Europe!" (I, 253). Buda is more conservative, ancient and quiet, but Paget correctly predicts that there will be a time when "the hills of Buda will be as well covered with suburban villas and mimic castles as Richmond or Hampstead" (I, 250). Therefore, he "foresee[s] a brilliant future for Buda-Pest" (I, 254), for which he most fervently wishes, for political reasons as well:

No one can wish its prosperity more sincerely than the author of these pages; for he believes that with it is closely associated the prosperity of all Hungary, and perhaps too the independence of the east of Europe. (I, 254)

But there is still much work to be accomplished between the two nations situated on the western and east-central "peripheries" of Europe. Both have to discover more about the other. Transportation should be developed, mainly for the sake of commerce, but also for making it possible for travelers to visit Hungary. Discussing the lack of economic relations between England and Hungary, Paget reports that he and one of his kind hosts

both regretted that between two nations who had each so much that the other required, such mutual ignorance should prevail, and we could only hope that steam-navigation would break down the barrier which had hitherto been found insurmountable. (I, 152) 
Paget's practical nature and liberal political convictions are reflected by his writing. He is at his best when he discusses politics and the forces that hinder economic and political development in the country. He comes to the conclusion that the underdeveloped conditions are only partly caused by Austrian hegemony; he sees the main culprit in obsolete Hungarian feudal laws for which, however, both the old-fashioned Hungarian nobility and the Austrian government are responsible. Paget's constant comparisons between Hungary and England reveal that he is on the side of the liberal political reformers.

\section{Civil rights, education, and women}

The historical parallels drive home the idea that Hungary is not as backward in constitutional rights as the average English reader would believe. It is surprising that the Magna Carta of England, created in 1215, for instance, is paralleled by the Bulla Aurea of 1222 in Hungary:

The English reader can scarcely fail to be struck by the singular coincidence of two countries, so far apart as England and Hungary, having obtained, within seven years of each other - the English in 1215, the Hungarians in 1222-, through the weakness of their monarchs, the great charters of their liberties. Nor, if he looks a little further, will he be less surprised to find that at the time the Hungarians were equal, if not before us, in enlightened notions of personal freedom, of civil rights, and of political privilege. It would be out of our province to investigate the causes which have produced the different results which we observe at the present moment; but I suspect a fair estimate of them would give us little cause for the indulgence of national vanity. The accident 
of geographical position has often worked mighty results in our favor and against the Hungarians. (I, 401)

But Paget is also critical of the nobles who wish to uphold their medieval rights of tax exemption instead of equally sharing the burden of taxation with the peasantry. He does not just describe, but also offers a solution for the problems of the oppressed peasantry. Although their situation cannot be compared to the conditions of peasants living in serfdom in Eastern Europe, they are still oppressed and taxed by heavy duties. Among the measures that the reformers demand, and which Paget also suggests, are the following:

Let the nobles gradually yield the vexatious rights of seigneury, which bring little profit to them, but do much injury to others; let them enable the peasant to purchase his freedom from service; grant him independent justice; as he acquires property, let him acquire consideration and rights; leave men and things to act as circumstances show to be best, untrammelled by restrictions, unaided by privilege; and the peasant of Hungary will soon occupy a position which may justly be envied by his fellows of any other part of Europe. (I, 316)

According to Paget, although the majority of the population does not have the right of suffrage, the proportion of voters compared to the rest of the population is noteworthy. He compares the Hungarian constituency to its English and French counterparts. In England, "one in twenty-five" is the proportion of voters representing the population; in France, it is "one in a hundred fifty;" and in Hungary, it is "one in twenty, if the number of adult males are considered; or one in seventy-five, if the whole population be taken" (I, 418). Paget admits that his purpose in presenting the statistical figures is to demonstrate that "it is not so small a 
proportion of the whole which governs Hungary as we are led to believe ... not so small as governs in democratic France at the present moment" (I, 418). Hungary's municipal system is also worth mentioning; in practice it is almost entirely free of Austrian interference, and it successfully instructs the people in their civil duties:

But, important as the county meetings are in their immediate effects, they are still more so in training the people to think of, and act in, the affairs of the county; and I am convinced it is to them we must attribute the fact, that in spite of the censorship of the press, in spite of their isolated position and the many other disadvantages which they labour under, the Hungarians have sounder notions of politics, and a better acquaintance with their own real interests, than many of the so-called highly civilized nations of Europe. (II, 61)

When Paget compares the position of women in Hungary and England, he draws the conclusion that Hungarian women enjoy more rights. Married women of the nobility and aristocracy in the Hungarian and Transylvanian societies are in a more advantageous legal and social position:

An Hungarian lady never loses her maiden name, and even during her husband's life, actions at law regarding her property are conducted in her name. Over her property the husband has by law no right whatsoever; even the management of it she may retain in her own hands, though she rarely or never does so. (II, 430)

Paget surprises his English readers by describing the social attitude toward divorce, more common among Protestants couples. If the reputation of the wife is spotless, she is not 
stigmatized by society as in England (II, 508-09). Clearly annoyed by the misinformation spread about Hungary and Hungarian women by other travelers, Paget takes pains to refute their assertions. According to the author of A Steam Voyage Down the Danube, M. J. Quinn, Hungarian ladies do not speak any other language than Hungarian. Paget assures his readers that

the education of Hungarian ladies, as far as languages are concerned, is very much more advanced than that of English or French ladies — ay, or gentlemen either-of the same rank. I have passed a considerable time in the country, and have had the opportunity of making the acquaintance of many Hungarian ladies, and I do not know one who speaks only Hungarian, though I do know several who do not speak that language. (II, 560)

When it comes to comparing the Austrian education system, which has also spread to Hungary and Transylvania, however, Paget is definitely in favor of the English system. He visits several, mostly denominational schools. Although Hungarians are only superior "in a minute knowledge of the laws of their own country; for the Corpus Juris forms an essential part of every Hungarian gentleman's education," they are less well-informed in literature, history, and the arts (I, 16). The children of the gentry do not attend boarding schools, and therefore cannot benefit from the "wholesome lessons which pride so often receives" in English schools (II, 504). The Austrian method of teaching in national and denominational schools is based on "stultification" (II, 536) and on acquiring too much "material knowledge." This model should not be imitated by the English: 
Do we find the Austrian in agriculture, in trade, in commerce, in the fine arts, in science, or in any one thing — save perhaps, fiddling and waltzing-before the rest of Europe? The government has been foolish enough to believe that it could use the energies of the human mind as it would those of a steam-engine - it has been ignorant of the well-known fact that it is only in freedom that the mind can work out anything pre-eminently good, whether in the sciences, in literature, or in the mere mechanical arts. (II, 537)

Comparing the denominational schools to one another, Paget draws the general conclusion that the Austrian method of teaching is applied "particularly among the Catholics" (II, 538). In consequence, the members "of the Unitarian and Lutheran churches, [are] the best educated" (II, 316).

\section{Protestant brethren and auto-images}

Armed with letters of introduction mainly from Polixéna Wesselényi, and István Széchenyi, Paget and his friends are welcome in a number of illustrious Hungarian households, whose names he is careful not to reveal. When he adopts the perspective of his Hungarian hosts, who belong mostly to the Hungarian Protestant nobility (except for the Catholic Count Széchenyi), he does so because he sees his own worldview, political and religious convictions, as well as his own aspirations for improvement reflected in those of his hosts. The desire for economic and political reform, including freedom from Austrian authorities, is supported by most of the Hungarian nobility and the middle class. In addition, the more he gets to know Hungarian history and culture, the more "English" traits he seems to discover in Hungarians. 
Protestants provide the best "mirror" through which Paget can see his own English identity reflected and reinforced in Hungary and especially in Transylvania. In a footnote he remarks that "the gentry" and the "lower nobles," just as the liberal delegates of the Lower Chamber of the Hungarian Parliament are mostly Protestants (I, 416). Wherever he meets Protestants, he recognizes them immediately and sketches a favorable picture of them, their appearance and manners, their homes and surroundings, which reflect their industrious and upright moral nature. The Cumanians of Kardszag ${ }^{13}$ are well-off and have an "easy look," and they are "among the best-built and most handsome of any part of Europe; their cottages characterized by "neatness and apparent comfort"” (II, 444). At Zsolna ${ }^{14}$ in Northern Hungary, the people going home from church possess "that steady, demure, and somewhat severe look which distinguishes the Protestant, find him where you will" (I, 108). After discovering that the Protestant College of Nagyenyed ${ }^{15}$ has long been supported by an annual sum of $£ 1000$, he remarks:

It is wonderful what a feeling of friendship, what a sentiment of brotherhood with England, this gift, though now completely forgotten among us, still maintains among the Transylvanian Protestants. (II, 386)

Whereas the Hungarian Protestants are grateful and remember their benefactors, the English have forgotten their brethren. It is especially the Unitarians of Transylvania, however, numbering at the time (according to Paget's source) "forty-seven thousand" (II, 502), most of whom are living in "Szekler-land," who are the closest to his heart (II, 398). A visit to Toroczkó, ${ }^{16}$ the Unitarian village, and the church and college in Klausenburg induces him to remark sorrowfully that "the great have fallen away ..., and the religion is now almost 
entirely confined to the middle and lower classes" (II, 503). He takes care to note that they can be distinguished from other Protestants:

Here as elsewhere, they are said to be distinguished for their prudence and moderation in politics, their industry and morality in private life and the superiority of their education compared to the generality of those of their own class." (II, 503)

Paget's sympathy for Protestants, especially Unitarians, cannot be denied. Simon Cooke argues that "however much [travel writing] purports to be an objective report on the world, it is always to some degree, consciously or not, a self-portrait-a record of a subjective individual or cultural point of view" (15). Thus the objectivity of Paget's work, just like other examples of travel writing, is nuanced by the author's subjectivity and his auto-image, despite the author's attempts to be as unbiased as possible. Paget's Hungary and Transylvania, just like other travel narratives of the period, has an autobiographical dimension. Throughout the Englishman's voyage of self-discovery, he is searching for the features that remind him of home and to which his readers can relate. The problem with the numerous different nationalities, for instance, was an issue which Victorian readers in an expanding imperial Great Britain could clearly recognize and comprehend.

\section{Nationalities and hetero-images}

Besides presenting romantic descriptions of picturesque landscapes, and describing the levels of hierarchy existing in Hungarian society, writing about the political, cultural and educational differences between Hungarian nobles and peasants, or drawing historical, political, and economic parallels between Hungary and England, Paget also draws attention to the ethnic, cultural, and linguistic divide that exists in the Carpathian Basin. Once again he is 
depending on his English readers to appreciate and wonder at novelties and the "Other," and to recognize the familiar, yet different imperial structure in which the various nationalities live under the laws of one ruling nation (Hungarians), under one King (Hungary), or under one Grand Prince (Transylvania), and one emperor; all of whom happen to be the same person: the emperor of the Central-European Austrian Empire. Paget's encounters with the different Central-Eastern European nationalities of Hungary and Transylvania are described through a subjective English lens, and result in a re-emergence of colonial discourse. The hetero-images of the various nationalities do not only originate in Hungarian sources and hearsay, but are based on his own English cultural and national self-image. He compares the relationship between Hungarians and the nationalities to that between the English and the peoples of the Celtic fringe. Paget's images of the multi-ethnic population of Hungary and Transylvania are similar to those of the Hungarians. Describing the history of the Slovaks, who were conquered by the Magyars in the ninth century, he compares their situation to those of the Celtic nations:

In Hungary, they seem to have experienced the same fate as the British in our own country, where the bleak mountains of Wales, the Highlands of Scotland, and the west-coast of Ireland have preserved the pure blood of Britain's earliest lords; while Saxon churls, and Norman soldiers appropriated her fairest fields to their own use. (I, 83)

The bagpipes of the Slovak and Wallach peasants, the plaids of the Wallach remind him of the Scots, (just like the Szeklers, and the Hungarian shepherds on the Puszta), although there are also Hungarian-Irish parallels. Consequently, the colonial discourse that he abandons when 
speaking about upper-class Hungarians, reappears when he is discussing the subject of the nationalities.

According to Carmen Maria Andras, "[t]he impressions that most British travelers had of Transylvania were filtered through the lens of the cultures of its Hungarian and Saxon inhabitants, as the native Romanian population was deprived of political, economic, religious, and cultural power" (1). Although Andras is right in asserting that British travelers like Paget were influenced by their Hungarian hosts, her claim regarding the oppressed status of the Romanian population should be more nuanced. It is important to see, for instance, that in the 1830s the reforms were aimed at abolishing the remnants of the feudal estates of the realm (the three orders of society), and ameliorating the political and economic situation of the peasants in general, irrespective of their nationality (Judson 111). Hungarian seigneurial laws applied to all peasants living on the property of the landlord, regardless of nationality. In Andras's view, Paget's text is biased, and his tone is "malicious" when he describes the lack of education among Romanian Greek Orthodox priests and the form of devotion of the Greek Orthodox Church, claiming that "[s]uch judgements were influenced not only by Paget's cultural values, but . . . [by] the opinions of the Hungarian aristocracy" (6). Paget's "cultural values," which may seem offensive today, however, were mostly influenced by his English Unitarian upper-class background and his family's important position in Leicestershire society (Wykes 54). The Catholic Church, a strong supporter of Habsburg rule, and her priests, just like the Hungarian Catholic absentee magnates, and the nobility who neglect their duties to the nation, are equally criticized in his narrative. Although Paget's hosts mostly belonged to the Hungarian Protestant nobility and aristocracy (with whom he spoke in German, French, or occasionally, English), he also had some contact with representatives of the middle-class and through interpreters, with the lower layers of the population. In this respect, Paget's writing also reflects that his own impressions and judgments regarding the 
nationalities were not simply based on the influence of his hosts, but on the hetero-images which his own cultural background generated. These subjective views, however, were shared by most of his Hungarian hosts.

In Hungary and Transylvania Paget recognizes the major problem that Hungary and the whole Austrian Empire would eventually have to face. In the preface to his work he refers to the colored map of Hungary and Transylvania printed in the book "to give a clear idea of one of the greatest national questions in Hungary - the division of its population into several distinct races, for the most part inhabiting different districts" (I, xii). Paget's critical comments about the Greek Orthodox clergy, the Russian political influence that sought to create a divide between Hungarians and the different Romanian and Slavic nationalities of the Kingdom and Principality, illustrate not simply a religious problem, but also a complex political issue. The question of the nationalities remained an unresolved problem for a long time. It increased in significance and contributed to the defeat of the Hungarian Revolution of 1848-49; it also led to the dissolution of the Austro-Hungarian Monarchy, and the tragic partition of historical Hungary after the Great War.

Writing about late nineteenth century British travelers to Hungary, Gephardt argues that

contemporary travelers . . recognized the parallels between the Irish and the Hungarians in their relationship with Austria as well as the Hungarians' aspiration to be seen as "the English of the East" and their corresponding treatment of the "races" they ruled. (170)

When Gephardt discusses the concept of internal colonization in Eastern Europe (146), she refers to the "Hungarians' dual role that resembles the position of both colonizers and 
colonized" (157). Although it is beyond the scope of this study to explain at further length why the terms "colonizers" and "colonized" are not applicable to the unique political position of Hungary in relation to Austria, why Hungary as a "colonizer" in relation to the nationalities inhabiting its territory is completely misleading, still, there are certain parallels which can be observed. Paget, for instance, moderately agrees with the "Magyarizing" tendencies in Croatia (then a province of Hungary), where the official Latin was abolished in favor of Hungarian in public offices, but not with the method of speedily executing the measure in ten years (II, 589). Nor does he agree with the Croatian policy of prohibiting Protestants from landownership within their borders. As freedom of religion is an important civil right for the Unitarian Paget, he prefers to sympathize with the Hungarian and Transylvanian example of freedom of worship. However, he cannot agree with the "violent" manner in which the measures are introduced:

No one can doubt how highly conducive it would be to the good of Hungary that Croatia should be made completely Hungarian; or that it is disgraceful to the age in which we live, that Protestants should be excluded from a whole country on account of their faith; yet indubitable as are these facts, it may nevertheless be very impolitic to seek to remedy them by violent means. (II, 589)

As an Englishman coming from the multi-ethnic British Empire, Paget undoubtedly shares the views of Hungarians concerning the political and national unification of a country divided by a diverse linguistic population, so difficult to rule from the royal (Buda) and the imperial center (Vienna). But he also censures "the pride of the Magyar, . . . one of his strongest traits," which "leads him to look down upon ever other nation by which he is surrounded with sovereign contempt" (II, 20). 


\section{Conclusion}

Despite the criticism of all the external and internal factors which impede the political, economic, and social development in Hungary and Transylvania, Paget's overall impression is favorable concerning the potential the nation has due to its geographical position in the region. The further Paget proceeds with the account of his travels across Hungary and Transylvania, the more at home he seems to feel: "I think I hear an old English squire exclaim 'Hem! I do believe a man might live in Hungary"' (I, 285). By the end of the second volume Paget abandons descriptions of the romantic and the picturesque; he also forgets to use the colonial discourse of the English traveler in relation to Hungarians. Instead, he pragmatically contemplates future British-Hungarian commercial relations, beneficial for both parties, warmly supporting the Hungarian Diet's request that there should be an English "consulgeneral established at Pest" (II, 624). "Would that my appeal might reach them! A little exertion on their part might secure to England not only a good customer, but what is more important, a true and faithful ally" (II, 624-25).

But first, Austria would have to understand "the importance of strengthening the Danubian provinces," and Hungarians would also have to introduce their own reforms to "strengthen the position of Hungary" (II, 620). If Great Britain were to promote commercial relations with the Hungarian Kingdom and Transylvanian Principality lying in East-Central Europe, these territories would be gradually integrated into the mainstream of European economy. Paget's optimistic text vaguely hints at the possibility of Hungary becoming a possible future political and free "ally," rather than an "imagined" colony of England. Hungary and Transylvania, therefore, suggests the necessity of western integration for a land which has for centuries, successfully, and often unsuccessfully, attempted to orient its politics 
toward the West rather than the East, emphasizing the benefits that England and the CentralEuropean nation would mutually enjoy from such an alliance.

Paget's text reveals that by exploring the country, and making himself familiar with the existing conditions and analyzing them, he was also mapping out a future for himself. He especially appreciated what he recognized as familiar, sounding optimistic about the future of the nation, and the country where he was contemplating to settle down. When his book was finally published in 1839 , he was already determined to spend his life with a Hungarian woman, Polixéna Wesselényi, for whom he had special "affection and esteem," and to whom his long work was dedicated (I, v). ${ }^{17}$ Besides offering glimpses into Paget's political and cultural values, and into his inner self, the greatest merit of Paget's Hungary and Transylvania lies in its comprehensive quality and in its placing what at the time seemed to English readers as a peripheral Central-European nation into the spotlight in early Victorian travel writing. There it remained as a model for future British travel writers throughout the rest of the nineteenth century.

Pázmány Péter Catholic University

\section{Notes}

${ }^{1}$ Bratislava (Pozsony in Hungarian), the capital of Slovakia today. Paget consistently uses the German name of the former capital of the Kingdom of Hungary (1536-1783), which was losing its political importance by the 1830s, although the Hungarian Diet was still held there. The session of the Diet mentioned by Paget was held between 1832 and 1836 .

${ }^{2}$ All in-text page references to Paget's two-volume book are to the first edition: Hungary and Transylvania; with Remarks on their Condition, Political, Economical, and Social (London: John Murray, 1839). 
3 When using the term "East-Central Europe," I am positioning Hungary and Transylvania geographically in Central Europe based on Jenő Szücs's highly influential study on the three historically and culturally separate European regions. See Szücs's "The Three Historical Regions of Europe: An Outline." Maria Todorova contests the justifiability of Szücs's interpretation of "Central Europe," and the term itself, by referring to it as a "myth" that is "insidious" (160), but Paget's text clearly differentiates culturally between Hungary, Transylvania, and the countries which were at the time still under Turkish rule or under Russian influence. See especially the cultural differences described in Chapter IV (II, 127-29) on the visit to the Pasha of Orsova in Paget's Hungary and Transylvania.

${ }^{4}$ See for instance, Sándor Kovács’s biography of Paget: 'Kétszáz éve született John Paget, Erdély magyar honpolgára" [John Paget, a Hungarian citizen of Transylvania, born two hundred years ago], Keresztény Magvető 114:2 (2008): 203-18. János Kovács, Sándor Fest, and Joseph Balogh were notable scholars with publications on the subject many years earlier.

${ }^{5}$ Frances Trollope also published Vienna and the Austrians in 1838, a year before Paget's work appeared, but she did not visit Hungary.

${ }^{6}$ Most biographical sources mention that Paget toured Greece and Turkey with the future Hungarian Prime Minister, Lajos Batthány, who was executed by the Austrian authorities for his role in the 1848-49 Hungarian revolution by a firing squad. David L. Wykes, and some Hungarian sources mention this detail, but I could find no substantial proof for these claims. However, Kázmér Batthyány, the Foreign Minister of the Szemere Cabinet in 1849, was Paget's close friend and they may have made the tour together.

Paget participated in the Hungarian Revolution as a member of the National Guard, later serving as a cavalry officer under Colonel János Czetz. In 1850 he returned to England with the intention of publishing his memoirs on the Revolution. John Murray, however, 
decided to reprint Hungary and Transylvania instead, and the unfinished manuscript was never published.

${ }^{8}$ Transylvania and Hungary were united until 1526, when the Turkish conquest led to the tripartite division of the former Kingdom. The Compromise of 1867 reunited Transylvania with Hungary within the new governmental and empirical structure of the dual AustroHungarian Monarchy.

${ }^{9}$ George E. Hering published a volume full of colored lithographic plates based on the sketches made during his travels with Paget in Sketches on the Danube; Hungary and Transylvania (London: Thomas McLean, 1838), to which Paget wrote the preface.

${ }^{10}$ Kinga Székely’s article, “Egy magyarrá vált nemes barlangleírásai” [Descriptions of caves by an English nobleman, who has become Hungarian], discusses Paget's visits to the dripstone caves of Hungary.

${ }^{11}$ Kolozsvár in Hungarian, officially Cluj in present-day Romania. Paget consistently uses the German names of towns.

${ }^{12}$ The interest was mutual. In 1903 Arthur Griffith, the Irish politician and statesman, would write a pamphlet on The Resurrection of Hungary: A Parallel for Ireland, seeing in the Austro-Hungarian Monarchy the example to follow for Ireland in its relationship with Great Britain.

${ }^{13}$ Karcag, Hungary.

${ }^{4}$ Žilina in Slovakia.

${ }^{15}$ Aiud in present-day Romania.

${ }^{16}$ Rimetea in present-day Romania.

${ }^{17}$ Baroness Polixéna Wesselényi. 


\section{Works Cited}

Andras, Carmen Maria. “The Image of Transylvania in English Literature.” 1-9. Web. 9 Jan. 2020.

Bökös, Borbála. "Representations of Hungary and Transylvania in John Paget's Travelogue." Acta Universitatis Sapientiae Phililogica 9.1 (2017): 87-98. Web. 9 Jan. 2020.

Cooke, Simon. "Inner Journeys: Travel Writing as Life Writing.” The Routledge Companion to Travel Writing. Ed. Carl Thompson. London, New York: Routledge, 2016. 15-24. Print.

Gephardt, Katarina. The Idea of Europe in British Travel Narratives, 1789-1914. Aldershot and Burlington: Ashgate, 2014. Print.

Hammond, Andrew. "Imagined Colonialism: Victorian Travellers in South-East Europe." Ninteenth-Century Contexts 28:2 (2006): 87-104. Web. 1 Sep. 2020.

Judson, Pieter M. The Habsburg Empire; A New History. Cambridge, Mass.: Harvard UP, 2016. Print.

Kabdebo, Thomas. "Travellers to Hungary: Blackwell's Predecessors." The Maynooth Review/Revieú Mhá Nuad 9.12 (1983): 31-48. JSTOR. Web. 9 Jan. 2020.

Kovács, Sándor “Kétszáz éve született John Paget, Erdély magyar honpolgára” [John Paget, a Hungarian citizen of Transylvania, born two hundred years ago]. Keresztény Magvetó 114.2 (2008): 203-18. Web. 10 Jan. 2020.

Leersson, Joep. "Imagology: History and Method." Imagology: The Cultural Construction and Literary Representation of National Characters. A Critical Survey. Ed. Manfred Beller and Joep Leersson. Leiden: Brill/Rodopi, 2007. 17-32. Print.

Paget, John. Hungary and Transylvania; With Remarks on their Condition, Social, Political, and Economical. Vol.1-2. London: John Murray, 1839. Internet Archive. Web. 10 Jan. 2020 
Quadflieg, Helga. “'As mannerly and civil as any of Europe'; Early Modern Travel Writing and the Exploration of the English Self." Perspectives on Travel Writing. Ed. Glenn Hooper. London: Routledge, 2017. 27-40. Print.

Pratt, Mary Louise. Imperial Eyes; Travel Writing and Transculturation. London: Routledge, 2008. Print.

Steward, Jill. "Central Europe." Literature of Travel and Exploration. Ed. Jennifer Speake. Vol.1. London and New York: Routledge, 2003. Print.

Székely, Kinga. "Egy magyarrá vált nemes barlangleírásai” [Descriptions of caves by an English nobleman, who has become Hungarian]. Karszt és Barlang 1.1-2 (1992): 5360. Web. 9 Jan. 2020.

Szücs, Jenő, and Julianna Parti. “The Three Historical Regions of Europe: An Outline.” Acta Historica Academiae Scientiarum Hungaricae 29.2/4 (1983): 131-84. JSTOR. Web. 10 Jan. 2020.

Thompson, Carl. The Suffering Traveller and the Romantic Imagination. Oxford: Clarendon Press, 2007. Print.

Todorova, Maria. Imagining the Balkans. Oxford UP, 2009. Print.

Venkovits, Balázs. “Kelet és Nyugat Határán: Külföldi utazók Magyarországon és Debrecenben a 19. sz. első felében" [In the borderland between East and West: foreign travelers in Hungary, and in Debrecen]. Debreceni Szemle 25.4 (2017): 480-90.Web. 10 Jan. 2020.

Wykes, David L. “John Paget, M.D., of Transylvania (1808-1892)." Transactions of the Unitarian Historical Society 17.2 (1980): 54-72. Print. 